\title{
Effects of Syntactic Complexity on Sentence Comprehension in the Discourse of Persons with Aphasia
}

\author{
Hye Lim Kim, Jee Eun Sung \\ Department of Communication Disorders, Ewha Womans University, Seoul, Korea
}

Correspondence: Jee Eun Sung, PhD Department of Communication Disorders, Ewha Womans University, 52 Ewhayeodae-gil, Seodamun-gu, Seoul 03760, Korea

Tel: $+82-2-3277-2208$

Fax: +82-2-3277-2122

E-mail: jeesung@ewha.ac.kr

Received: July 5, 2016

Revised: November 2, 2016

Accepted: November 11, 2016
Objectives: The purpose of the current study was to investigate the effects of syntactic complexity on the accuracy of sentence comprehension in the level of discourse of persons with aphasia. Methods: Fourteen individuals with aphasia and 15 age and education-matched normal individuals participated in the study. Participants were presented with the same discourse contexts, but with different syntactic complexity. Syntactically simple discourse contained active sentences and conjoined sentences. On the contrary, syntactically complex discourse consisted of passive and embedded sentences. Accuracy (\%) served as a dependent measure in a sentence judgement task. Two-way mixed ANOVA, one-sample $t$ test, and correlation coefficients were performed. Results: For both simple and complex discourse types, people with aphasia (PWA) demonstrated greater difficulties than normal controls. Active and conjoined sentences were easier to process than passive and embedded sentence types. The two-way interactions were not significant. Discourse comprehension was, in general, related to aphasia severity and comprehension subtest scores of a standardized aphasia battery in the aphasic group. Conclusion: The results revealed that discourse comprehension was affected by the complexity of syntactic structures that composed discourse levels for PWA. Discourse that contained simple sentences elicited better performance than discourse with complex sentence types. It is clinically important to consider the level of syntactic complexity for assessment and treatment in a discourse level.

Keywords: Aphasia, Discourse, Syntactic complexity, Sentence comprehension ability
실어증 환자들은 언어 수행의 효율성이 저하됨에 따라 전반적인 혹은 특정한 언어 능력의 상실을 경험하게 되고 이로 인해 다양한 언어적 오류 양상을 보인다(McNeil \& Pratt, 2001).

Caramazza와 Zurif (1976)가 통사적 복잡성에 따른 문장이해에 어려움을 보인 실어증 환자군의 특징을 밝혀낸 이후로 문장이해에 대한 연구가 활발히 진행되었다. 실어증 환자의 문장이해에 대한 어려움을 설명하기 위해 여러 가설이 제시되었으나, 이는 크게 통 사론적 접근과 처리과정적 접근으로 구분할 수 있다. 통사론적 접 근은 문장이해의 어려움을 통사 규칙의 소실 또는 부분적인 결함 때문으로 설명하나(Caplan, \& Futter, 1986; Goodglass \& Hunt, 1958; Hagiwara, 1995; Schwartz, Saffran, \& Marin, 1980), 처리과
정의 문제로 보는 접근은 문장이해의 어려움이 처리과정상의 결함 으로 인해 문법 지식의 사용이 자유롭지 않기 때문에 일어난다고 보았다. 즉, 통사 규칙 자체의 소실보다는 수행 부진 때문에 발생한 다는 입장이다(Caplan \& Waters, 1999; Carpenter, Miyake, \& Just, 1994).

초기에는 실어증 환자의 문장이해에 대한 많은 연구들이 영어권 에 편중되어 있어 서로 다른 언어적 특성을 가지는 나라에 직접적 으로 적용하기 어려웠으나, 이후에는 각 나라의 언어적 특징을 반 영한 연구들이 많이 나오고 있는 실정이다. 영어권 연구에서는 주 로 의미역 또는 어순의 변화에 관심을 두고 실어증 환자들이 특정 한 구문 구조의 처리에 어려움을 겪으며, 그러한 문장 내의 단어들 
에 의미역을 할당하는데 제한을 갖는다고 보고하였다(Grodzinsky, 1995; Lee \& Thompson, 2004; Myers \& Blumstein, 2005). 상대 적으로 어순이 비교적 자유롭고 문법 형태소가 많은 한국어, 독일 어, 이탈리아어 등의 연구에서는 의미역 또는 어순의 변화뿐 아니 라 생물성, 문법 형태소 등 특정 언어의 특징을 반영하는 연구가 이 루어져왔다(Burchert, Bleser, \& Sonntag, 2003; Caplan, Waters, DeDe, Michaud, \& Reddy, 2007; Hwang JH, 2002; Hwang M, 2002; Nam, Yim, Jung, Kim, \& Pyun, 1999). 국내 실어증 환자들의 경우, 문장 내의 격조사 및 보조사 처리, 능동문 및 피동문 이해, 어순의 효과, 관계절 처리 또는 단어 수준에서 동사의 의미 범주에 따른 선 택적 결함 등과 관련된 연구들이 진행되었으며, 이와 관련된 문장 이해에 결함이 발견되었다고 밝혔다(Kim, 2010; Kim JH, 2002; Kim YJ, 2002; Yoon, 2002).

실어증 환자의 문장이해 결함과 관련된 많은 연구들 중에서도 대체로 문장의 통사적 복잡성과 관련된 연구 결과가 많다(Beretta, Piñango, Patterson, \& Harford, 1999). 이는 통사적 복잡성이 증가 할수록 실어증 환자들이 더 많은 문장이해 오류를 보이기 때문이 다. 단문의 형태에서는 주로 능동문과 피동문을 중심에 두고 그 이 외의 변수들을 추가한 연구들이 많이 이뤄졌다(Choi, 2012; Son, 2004). 이는 피동문의 경우 능동문과 비교하였을 때, 비전형적인 (non-canonical) 어순을 가짐과 동시에 서술 동사구의 행태 변동이 이뤄진 문장으로 통사적 복잡성이 훨씬 더 높은 형태 때문이다(Woo, 1997). 복문의 경우, 연결사 또는 연결어미로 이어진 접속문 보다 하 나의 문장이 절이 되어 다른 문장 성분으로 결합하는 내포문의 통 사적 복잡성이 더 높다고 할 수 있다. 실어증 환자들은 피동문과 더 불어 내포문의 이해에서도 어려움을 보였는데, 그 중에서 주절과 관계절의 행위자가 뒤바뀌어도 문장의 의미가 통하는 문장에서 특 히 더 어려움을 나타냈다(Caramazza \& Zurif, 1976). 한국어 실어 증 환자도 같은 맥락에서 통사적 처리 능력의 결함으로 인해 복문 중 관계절 문장이해 과제의 수행력이 떨어지는 것으로 나타났다 (Kim YJ, 2002).

실어증 환자의 문장이해 결함에 대한 연구는 비교적 널리 이뤄 졌지만, 문장이해를 담화 수준에서 살펴본 연구들은 국내 및 국외 모두 많지 않다. 담화이해 능력 결함에 대한 연구는 주로 우반구 손 상 환자 또는 치매를 가진 환자들을 대상으로 빈번하게 이루어졌 다(Baik, 2004; Kim, 2008; Kim, 2007; Kim, Yu, \& Jeong, 2004). 또 한, 실어증 환자를 대상으로 한 담화 능력 관련 연구라고 할지라도 표현 능력 고찰에만 집중되어 있을 뿐(Byun, Shin, Kim, \& Kim, 2009; Yang, 2000), 담화 내 문장이해를 중심으로 본 연구는 거의 없는 실정이다. Caplan과 Evans (1990)는 어순과 관련하여 통사적
복잡성에 차이를 둔 문장을 삽입한 담화 과제를 사용하여 실어증 환자의 담화 속 문장이해 능력을 살펴보았으며, Brookshire와 Nicholas는 개인의 담화이해 능력을 평가할 수 있는 표준화 도구인 the Discourse Comprehension Test (DCT; Brookshire, \& Nicholas, 1993) 와 the Discourse Comprehension Test-Revised (DCT-R; Brookshire, \& Nicholas, 2008)를 만들어 실어증 환자의 담화 내 문장이 해 능력을 알아보고자 하였다. 이들은 좌뇌 손상 환자, 우뇌 손상 환자, 외상성 뇌손상 환자를 대상으로 DCT에 대한 실험을 진행하 였고, 담화 내 명시된 직접적인 정보와 담화의 중심내용에 대한 질 문을 던졌다. 그 결과, 세 집단 모두 담화의 중심내용 질문에 대한 이해 정확도가 더 높게 나타났다. 국내에서는 L. Y. Kim (2015)이 경 도 실어증 환자의 듣기 및 읽기이해 능력을 문단과 담화 수준에서 살펴보았다. 그 결과, 경도 실어증 환자의 경우, 한국판 웨스턴 실어 증 검사(Korean version of Western Aphasia Battery, K-WAB; Kim $\& \mathrm{Na}, 2001)$ 에서는 듣기 이해력과 읽기 이해력에서 정상 집단과 큰 차이가 없었지만 담화 수준에서는 차이를 보였다고 하였다.

Nicholas와 Brookshire (1995)는 글의 구조와 언어적 맥락을 포 함하는 담화이해 측면의 중요성을 연구자들이 간과하고 있다고 하 였다. 담화는 맥락을 가지는 여러 층위의 구성요소로 이루어진 문 장의 상위 구조로 문장 보다 구조적, 기능적 관점에서 모두 문장보 다 높은 수준으로 이해되고 있다. 하지만 담화는 실제 일상생활에 서 문장보다 빈번하게 사용되는 의사소통 방법이다(Baik, 2004). 따라서 실어증 환자들의 효과적인 일상 복귀를 돕기 위해서는 문 장 수준뿐만 아니라 담화 수준에서의 평가 및 재활이 고려되어야 한다. 즉, 보다 심도 있는 재활을 위해 실어증 환자의 언어이해 결함 에 대한 문제를 더 정확히 알아보기 위해서는 담화 수준에서의 문 장이해 양상을 살펴보는 것이 필요하다. 위에서 언급한 L. Y. Kim (2015)의 연구는 외국인을 대상으로 만들어진 한국어능력시험을 참조하여 문항을 만들었으며, 경도 실어증 환자의 담화 수준에서 의 전반적인 이해 및 표현 능력을 평가하였다. 그러나 본 논문에서 는 실어증 환자의 이해 능력 평가에 집중하여, 실어증 환자들이 단 순 문장 수준에서도 특히 어려움을 나타내는 부분이 맥락을 포함 하는 담화에 적용되었을 때에도 동일한 어려움을 나타내는지 알아 보고자하였다.

따라서 본 논문은 담화 내 문장의 통사적 복잡성을 달리하여 능 동문과 접속문이 삽입된 담화는 단순한 담화로, 피동문과 내포문 이 삽입된 담화는 복잡한 담화로 설정하였고, 실어증 환자와 정상 집단 간 단문과 복문, 담화 내 마지막 문장이해 능력을 평가하고자 한다. 즉, 실어증 환자들이 단순 문장이해에서와 마찬가지로 담화 에서도 동일한 문장이해의 어려움을 보이는지, 담화 내 문장이해 
의 어려움이 담화 전체 맥락이해에 영향을 주는지 고찰해보고자 한다.

본 연구의 구체적인 질문은 다음과 같다.

첫째, 담화 내 단문(능동문 vs. 피동문)이해 정반응률에서 실어 증 환자와 정상 집단 간 차이가 유의한가?

둘째, 담화 내 복문(접속문 vs. 내포문)이해 정반응률에서 실어 증 환자와 정상 집단 간 차이가 유의한가?

셋째, 담화 내 문장의 통사적 복잡성에 따라 담화 마지막 문장이 해 정반응률에서 실어증 환자와 정상 집단 간 차이가 유의한가?

넷째, 실어증 환자군에서 통사적 복잡성에 따라 구성된 담화이 해 능력과 실어증 중증도 및 표준화 검사 내 이해 하위검사 점수와 의 상관관계가 어떠한가?

\section{연구 방법}

\section{연구 대상}

본 연구는 정상 성인 15 명과 실어증 환자 14 명을 대상으로 실시 하였다. 실어증 환자는 서울 또는 경기도 소재 종합병원 및 재활병 원의 재활의학과에 입원 또는 내원하고 있는 환자 중에서 모집하였 으며, 정상 성인은 서울 및 경기도에 거주하고 있는 자를 대상으로 모집하였다. 대상자의 각 집단별 선정기준은 다음과 같다.

실어증 환자는 (1) 좌뇌의 피질 및 피질하 부위 또는 뇌간의 뇌졸 중으로 인해 언어장애를 보이는 자와 외상성 뇌손상 또는 뇌종양 에 기인하나 좌뇌 병변으로 인해 언어장애가 동반되는 자, (2) 한국 판 웨스턴 실어증검사(K-WAB; Kim \& Na, 2001) 결과, 실어증으로 분류된 자, (3) 발병 이전에 뇌손상 및 기타 신경학적 질환이 없었다 고 보고된 자, (4) 산출은 불가하더라도 듣기 및 읽기에 대한 이해가 가능해야 하므로 K-WAB검사 결과, 알아듣기 영역이 경도(mild)에 서 중도(moderate)에 해당하는 자, (5) 연령과 교육수준의 차이가 수행에 미치는 영향을 최소화하기 위해 75세 이하이며, 학력이 초졸 이상인 자를 대상으로 선정하였다(Kang, Chin, Na, Lee, \& Park, 2000).

정상 성인은 (1) 실어증 환자 집단과 평균 연령 및 평균 교육연수 가 일치하는 자, (2) 간이정신상태검사(Korean-Mini Mental State Examination, K-MMSE; Kang, 2006) 실시 결과, 정상 범위에 해당 하는 자, (3) 그 외에 언어 및 신경학적 손상, 병력이 보고되지 않은 자를 대상으로 하였다.

모든 대상자는 과제 수행을 위해 시력과 청력에 문제가 없는 자 로 선정하였으며, 모두 오른손잡이를 대상으로 하였다. 대상자 정 보는 Appendixes 1과 2에 제시하였다.
집단별 연령과 교육연수에 유의한 차이가 있는지 알아보기 위하 여 두 독립표본 $t$ 검정(two-independent samples $t$-test)을 실시하였 고, 그 결과, 연령 $\left(t_{27}=-.205, p=.384\right)$ 과 교육연수 $\left(t_{27}=-.612, p=.084\right)$ 모두 집단 간차이가 통계적으로 유의하지 않은 것으로 나타났다.

\section{담화 및 문장 과제}

본 연구에서는 담화속 문장이해 능력을 측정하기 위해 연구자가 선행연구를 바탕으로 검사 도구를 제작하였다(Levy et al., 2012). 실험 속 담화는 단순한 담화와 복잡한 담화로 나뉘며, 두 담화의 내 용은 동일하나, 단지 담화를 이루는 문장의 통사적 복잡성에 차이 가 있다. 본 연구에서는 '통사적 복잡성'을 문장의 어순, 문장 내 구 성 성분 간의 관계로 결정되는 문장 유형, 문장 결합방식 등에 한정 하여 살펴보았다. 즉, 문장의 어순이 비전형적(non-canonical)일수 록, 문장 성분 간 관계 또는 문장 결합방식이 복잡할수록 통사적 복잡성이 더 높다고 할 수 있겠다. 따라서 본 연구 과제에서는 단문 의 경우, '행위자(agent)-대상(theme)'의 전형적인 어순을 가진 능 동문보다 '대상(theme)-행위자(agent)'의 비전형적인 어순을 가진 피동문의 통사적 복잡성이 더 높다고 규정한다. 피동문의 경우, 의 미역(thematic role)의 위치 변환과 동시에 서술 동사구의 일부 구 성요소의 행태 변동이 이뤄져 그 복잡성이 더욱 가중된다. 복문의 경우, 두 개의 문장이 연결사 또는 연결어미로 이어진 접속문보다 하나의 문장이 절이 되어 다른 문장 성분으로 결합하는 내포문의 통사적 복잡성이 더 높다고 규정한다. 내포문 중에서도 관형사절 내포문을 사용하며, 그 중에서도 주절과 관계절의 공통참조 의미 역이 동일하지 않은 ‘주어수식-목적격관계절'(Subject-Object, SO) 을 사용하였다. 능동문과 접속문이 삽입되어 상대적으로 단순한 문장구조가 사용된 담화를 단순한 담화로, 피동문과 내포문이 삽 입되어 상대적으로 복잡한 문장구조가 사용된 담화를 복잡한 담 화로 설정하였다.

두 담화에 쓰인 목표문장은 능동문, 피동문, 접속문, 내포문으로 총 4 가지다. 우선, 피동문을 실현하는 방법은 여러 가지가 있으나 본 연구에서는 '-이-, -히-, -리-, -기'를 사용하여 접미사를 첨가하 는 방법으로 피동문을 만들었으며, 피동문의 기저가 되는 문장을 능동문으로 사용하였다. 능동문과 피동문에 사용된 동사는 동사 하나에 필수 문장 성분 두 개를 필요로 하는 2 항 타동사이다. 접속 문을 만드는 방법은 연결어미 '고'를 사용하는 것이 대표적이며, 동 일한 방법으로 만들었다. 한국어에서 내포문은 크게 세 가지로 분 류되나(Lee, 2001), 본 연구에서는 관형사형 어미 '-은, '-는', '-을'을 사용한 관형사절 내포문을 사용하였다. 접속문과 내포문에 사용 된 동사는 동사 하나에 필수 문장 성분 두 개 또는 세 개를 필요로 
하는 2항 또는 3 항 타동사이다. 목표문장에 사용된 동사는 사용 횟수를 3 회 이하로 하였고, 문장이해 판단과제 실시 시, 같은 동사 가 판단문장에 연달아 나오지 않도록 설정하였다.

통사적으로 복잡한 문장이 담화에 삽입됨으로 담화 전체 이해 에 영향을 미치는지 알아보기 위해 담화의 맨 마지막에 삽입된 문 장이해에 대한 정반응률을 분석하였다. 담화의 맨 마지막 문장은 담화의 흐름에 알맞은 문장이나 단순한 담화나 복잡한 담화에 동 일하게 사용되는 문장으로 문장의 통사적 복잡성을 다르게 설정하 지 않은 문장이다. 이는 통사적으로 복잡한 문장을 이해하기 위해 서는 인지 부하가 높아져 정반응률이 낮아진다는 선행연구에 기반 하여 이와 같은 적용이 담화에서도 이뤼지는지 알아보기 위해 사 용되었다.

실험 문장에 쓰인 어휘는 세종 말뭉치 2010년 배포판(Lee, Yeon, Hwang, \& Lee, 2010)에서 빈도 100 이상의 고빈도 어휘를 중심으 로 선정하였다. 사용된 명사는 일반명사이며, 필요에 의해 고유명 사가 사용된 경우, 빈도 100 이상의 고빈도 단어를 사용하였으나 일반명사와 고유명사의 친숙도에 차이가 있을 수 있기 때문에 목표 문장에서는 사용이 제외되었다.

한국어의 통사적 복잡성에 근거한 문장 유형 분류에 따라 단순 한 담화에는 능동문과 접속문이 삽입되었고, 복잡한 담화에는 피 동문과 내포문이 삽입되었다. 실험에 사용된 두 담화의 예시는 Appendix 3 에 제시하였다. 자극의 통일성을 유지하고, 개인별 기억력 효과를 최대한 통제하기 위해 능동문과 피동문은 세 번째 줄에, 접 속문과 내포문은 다섯 번째 줄에 동일하게 배치하였다.

실험에 사용된 담화는 단순한 담화와 복잡한 담화가 각각 8 개의 주제로 총 16 개로 구성된다. 단순한 담화와 복잡한 담화에 대한 통 사적 복잡성의 차이를 명시하기 위해 단순한 담화 8 개, 복잡한 담 화 8 개를 구문을 분석하여 독립표본 $t$ 검정(independent samples $t$ test)을 실시하였으며, 그 결과, 단순한 담화와 복잡한 담화의 문장 을 구성하는 조사, 명사, 동사, 형용사, 부사, 총 단어 개수에서 통계 적으로 차이가 유의하지 않았다. 즉, 두 담화는 담화를 이루는 문 장 구성 성분에는 차이가 없었다. 다만, 단순한 담화와 복잡한 담화 는 담화를 구성하는 문장의 통사적 복잡성에만 차이가 있다.

대상자에게 제시되는 담화는 단순한 담화와 복잡한 담화 각각 8 개씩 총 16 개로 무작위 순서로 제시되었으나, 먼저 읽은 담화의 영 향을 최소화하기 위해 같은 내용의 단순한 담화와 복잡한 담화는 최소 4 개 이상 떨어뜨려 놓았다. 또한, 담화 제시 순서가 전혀 반대 인 실험 세트를 하나 더 만들어 대상자의 반은 1 번 세트, 나머지 반 은 2 번 세트를 활용하여 대상자별 담화 순서의 영향을 최소화하도 록하였다.
담화 속 문장 이해능력을 측정하기 위해 제시된 담화에 대한 이 해를 마친 뒤, 담화 내 문장과 관련된 판단문장을 제시하고 판단문 장이 앞서 이해한 담화에 부합하는지 부합하지 않는지를 ‘예', ‘아니 오'로 판단하도록 하였다. 각각의 담화에는 능동문과 피동문에 대 한 판단문장 1 개, 접속문과 내포문에 대한 판단문장 1 개, 담화 마지 막 문장에 대한 판단문장 1 개로 총 3 개의 문장이 제시된다. 판단문 장은 과제의 난이도를 고려하여 목표문장의 형태와 관계없이 능 동 문 형태로 제시되며, 3 개 문장의 제시 순서는 무작위로 하였다. 내 포문에 대한 판단문장의 경우, 내포된 문장을 이해했는지 측정하 기 위해 주절이 아닌 관계절에 대한 판단문장을 사용하였다. 판단 문장의 정반응이 ‘예' 또는 ‘아니오'가 될 가능성은 항상 $50 \%$ 로 모 든 담화가 동일하다. 판단문장의 예시는 Appendix 4 에 제시하였다.

\section{연구 절차}

모든 피험자에게 개별적으로 실시되었으며, 소음 요인을 배제하 기 위해 조용한 장소에서 실시하였다. 실험에는 이프라임(E-Prime 2.0) 프로그램이 설치된 컴퓨터가 사용되었다. 프로그램은 선행연 구를 바탕으로 연구자가 직접 제작하여 Window 환경에서 실행하 였다. 화면의 바탕은 흰색이었으며 글자는 검정색으로 화면 중앙에 제시되었다. 글자 모양은 맑은고딕이며, 글자 크기는 35포인트(point) 로 설정하였다. 응시점(+)이 $1,000 \mathrm{~ms}$ 동안 제시된 이후에 자동으 로 화면이 바뀌면서 전체 담화가 화면에 나타난다. 대상자는 제시 된 담화를 눈으로 봄과 동시에 귀로도 담화를 듣게 된다. 이때, 청각 적으로 제시되는 담화는 연구자의 목소리로 녹음되었다. 담화에 대한 이해가 끝나면 스스로 스페이스바를 눌러 다음으로 넘어가도 록 하였고, 넘기지 않았을 경우 담화이해의 최대 시간은 5 분으로 한정하였다. 이후에는 담화와 관련된 3 개의 판단문장이 하나씩 제 시되며, 대상자는 '예' 또는 '아니오' 버튼을 눌러 응답하도록 하였 다. 하나의 판단문장에 대한 응답이 끝나면 바로 다음 판단문장이 제시되도록 하였다. 버튼은 노트북의 키보드를 사용하였으며, '예' 버튼은 ' $\mathrm{Z}$ '로 '아니오'버튼은 ' 주지 않기 위해 해당 버튼 위에 초록색으로 '예', 빨간색으로 ‘아니 오'를 명시하였으며, 화면에도 판단문장과 함께 ‘예’, ‘아니오' 버튼 의 색깔과 위치를 제시하였다. 응답이 모두 끝나면 빈 화면이 1,500 $\mathrm{ms}$ 동안 제시된 후 다음 담화가 나타나도록 하였다.

\section{자료 분석}

대상자가 제시된 담화를 읽은 후, 나오는 판단문장에 정반응 한 경우 1 점, 오반응 한 경우 0 점으로 하였다. 대상자는 각 조건별로 정 반응 한 문항 수를 각 조건별 총 문항 수인 8 로 나눈 후 100 을 곱하 
여 정반응률(\%)을 계산하였다.

수집된 자료는 SPSS 18.0 통계프로그램으로 분석하였다. 담화 내 문장의 통사적 복잡성을 달리하였을 때, 첫째, 단문(능동문 vs. 피동문)에서, 둘째, 복문(접속문 vs. 내포문)에서 실어증 환자 집단 과 정상 성인 집단 간 담화 속 문장이해 정반응률에 차이가 있는지 알아보기 위해 각각 이원혼합분산분석(two-way mixed ANOVA) 을 실시하였다. 셋째, 담화 내 문장의 통사적 복잡성을 달리한 담화 의 마지막 문장이해 정반응률을 비교하였을 때, 실어증 환자 집단 과 정상 성인 집단 간 차이가 있는지 알아보기 위해 이원혼합분산 분석(two-way mixed ANOVA)을 실시하였다. 넷째, 실어증 환자 집단과 정상 성인 집단의 문장이해 판단 과제에 대한 수행력이 우 연 수준(chance level) 이상인지 알아보기 위해 일표본 $t$ 검정(onesample $t$-test)을 실시하였다.

통계 기술의 유의수준은 $p=.05$ 를 기준으로 하였으나, 구체적인 통계 수치 기술에서 기준 유의수준보다 낮게 나온 경우, $p$-value가 보다 낮게 나왔음을 시사하기 위해 $p$-value에 최대한 가까운 근접 수치를 서술하였다.

\section{연구 결과}

\section{통사적 복잡성에 따른 담화 속 단문이해에서 집단 간 정반응률} 분석

담화 내 문장의 통사적 복잡성에 따라 단문(능동문 vs. 피동문) 에서 실어증 환자와 정상 집단 간 담화 속 문장이해 정반응률을 분 석한 결과, 집단 간 주효과가 통계적으로 유의하였다 $\left(F_{(1,27)}=8.797\right.$,

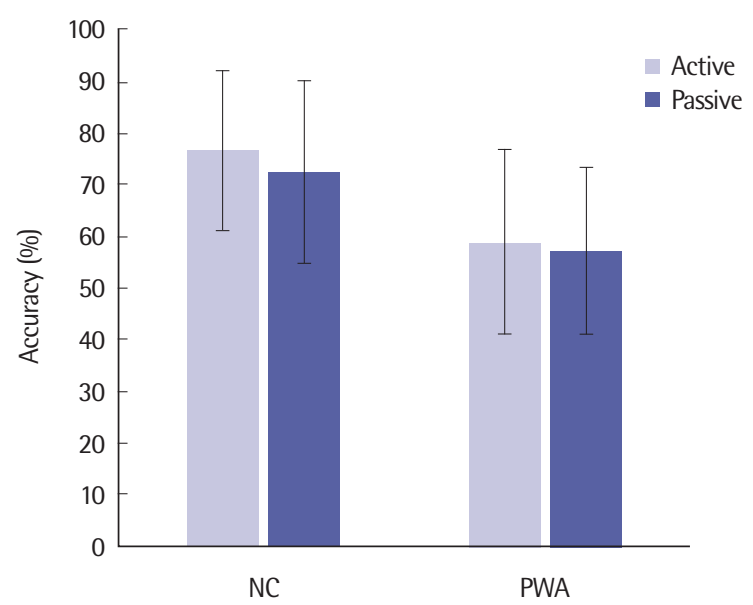

Figure 1. Comparisons between active and passive sentences in normal controls (NC) and persons with aphasia (PWA). Error bar indicates standard deviation. $p<.01)$. 즉, 정상 집단의 정반응률이 실어증 환자보다 유의하게 더 높은 것으로 나타났다. 담화 내 문장의 통사적 복잡성에 따른 단문 이해에 대한 주효과는 통계적으로 유의하지 않았다 $\left(F_{(1,27)}=1.080\right.$, $p>.05)$. 즉, 담화 내 능동문과 피동문에서의 정반응률은 유의한 차 이가 없었다. 담화 내 문장의 통사적 복잡성에 따른 단문에서 집단 간 상호작용은 유의하지 않았다 $\left(F_{(1,27)}=.173, p>.05\right)$ (Figure 1).

실어증 환자와 정상 집단의 단문(능동문 vs 피동문)이해 과제에 대한 수행력이 우연 수준(chance level) 이상인지 알아본 결과, 실어 증 환자의 단문이해 평균 정반응률은 능동문 $\left(t_{14}=1.859, p>.05\right)$ 과 피동문 $\left(t_{14}=1.665, p>.05\right)$ 모두 95\% 신뢰수준에서 통계적으로 유 의하지 않은 것으로 나타났다. 즉, 실어증 환자의 단문이해에 대한 정반응률이 우연 수준과 유의하게 차이가 나지 않았다. 정상 집단 의 단문이해 평균 정반응률은 능동문 $\left(t_{15}=6.631, p<.001\right)$ 과 피동 문 $\left(t_{15}=4.895, p<.001\right)$ 모두 $95 \%$ 신뢰수준에서 통계적으로 유의한 것으로 나타났다. 즉, 정상 집단의 단문이해에 대한 정반응률은 우 연 수준보다 유의하게 높은 것으로 나타났다.

\section{통사적 복잡성에 따른 담화 속 복문이해에서 집단 간 정반응률 분석}

담화 내 문장의 통사적 복잡성에 따라 복문(접속문 vs. 내포문) 에서 실어증 환자와 정상 집단 간 담화 속 복문이해 정반응률을 분 석한 결과, 집단 간 주효과가 통계적으로 유의하였다 $\left(F_{(1,27)}=6.148\right.$, $p<.05)$. 즉, 정상 집단의 정반응률이 실어증 환자보다 유의하게 더 높은 것으로 나타났다. 담화 내 문장의 통사적 복잡성에 따른 복문 이해에 대한 주효과는 통계적으로 유의하지 않았다 $\left(F_{(1,27)}=1.960\right.$,

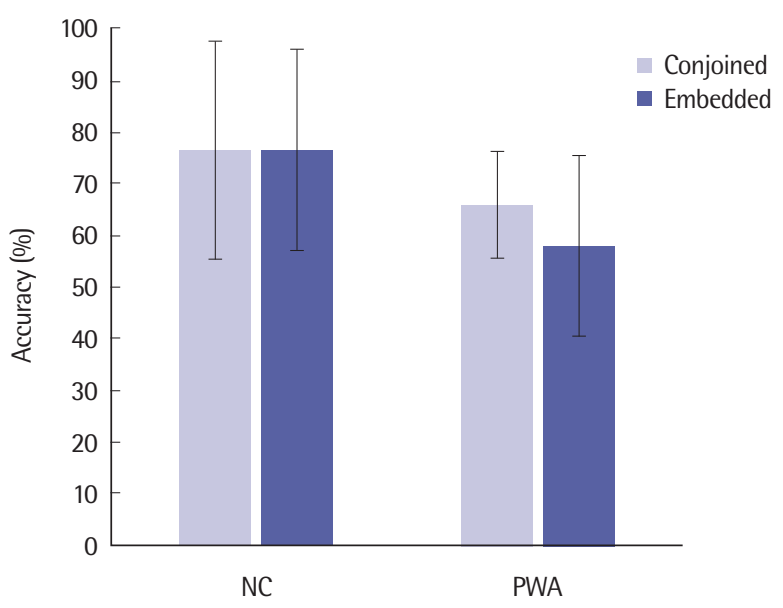

Figure 2. Comparisons between conjoined and embedded sentences in normal controls (NC) and persons with aphasia (PWA). Error bar indicates standard deviation. 
$p>$.05). 즉, 담화 내 접속문과 내포문에서의 정반응률은 유의한차 이가 없었다. 담화 내 문장의 통사적 복잡성에 따른 복문에서 집단 간 상호작용 효과 또한 유의하지 않았다 $\left(F_{(1,27)}=1.960, p>.05\right.$ ) (Figure 2).

실어증 환자와 정상 집단의 복문(접속문 vs. 내포문)이해 과제에 대한 수행력이 우연 수준(chance level) 이상인지 알아본 결과, 실어 증 환자의 복문이해 평균 정반응률은 내포문의 경우, $95 \%$ 신뢰수 준에서 통계적으로 유의하지 않은 것으로 나타났으나 $\left(t_{14}=1.859\right.$, $p>.05)$, 접속문의 경우, 통계적으로 유의한 것으로 나타났다 $\left(t_{14}=\right.$ $6.032, p<.001)$. 즉, 실어증 환자의 내포문 이해에 대한 정반응률은 우연 수준과 유의한 차이가 나지 않았으나, 접속문 이해에 대한 정 반응률은 우연 수준보다 유의하게 높은 것으로 나타났다. 정상 집 단의 복문이해 평균 정반응률은 접속문 $\left(t_{15}=4.904, p<.001\right)$ 과 내 포문 $\left(t_{15}=5.323, p<.001\right)$ 모두 $95 \%$ 신뢰수준에서 통계적으로 유의 한 것으로 나타났다. 즉, 정상 집단의 복문이해에 대한 정반응률은 우연 수준보다 유의하게 높은 것으로 나타났다.

\section{통사적 복잡성에 따른 담화 속 마지막 문장이해에서 집단 간 정반응률 분석}

통사적으로 복잡한 문장이 담화에 삽입됨으로 담화 전체 이해 에 영향을 미치는지 알아보기 위해 담화의 맨 마지막에 삽입된 문 장이해에 대한 정반응률을 분석한 결과, 집단 간 주효과가 통계적 으로 유의하였다 $\left(F_{(1,27)}=14.796, p<.01\right)$. 즉, 정상 집단의 정반응률 이 실어증 환자보다 유의하게 더 높은 것으로 나타났다. 담화 내 문 장의 통사적 복잡성에 따른 마지막 문장이해에 대한 주효과도 통 계적으로 유의하였다 $\left(F_{(1,27)}=4.907, p<.05\right)$. 즉, 통사적으로 단순한 담화에서의 정반응률이 복잡한 담화에서 보다 유의하게 더 높은
것으로 나타났다. 담화 내 문장의 통사적 복잡성에 따른 마지막 문 장이해 정반응률과 집단 간 상호작용은 유의하지 않았다 $\left(F_{(1,27)}=\right.$ $.006, p>.05$ ) (Figure 3).

실어증 환자와 정상 집단의 마지막 문장이해 과제에 대한 수행력 이 우연 수준(chance level) 이상인지 알아본 결과, 실어증 환자의 마지막 문장이해 평균 정반응률은 단순한 담화 $\left(t_{14}=3.000, p<.05\right)$ 와 복잡한 담화 $\left(t_{14}=3.017, p<.05\right)$ 에서 모두 $95 \%$ 신뢰수준에서 통 계적으로 유의한 것으로 나타났다. 즉, 실어증 환자의 마지막 문장 이해에 대한 정반응률은 우연 수준보다 유의하게 높은 것으로 나 타났다. 정상 집단의 마지막 문장이해 평균 정반응률은 단순한 담 화 $\left(t_{15}=14.554, p<.001\right)$ 와 복잡한 담화 $\left(t_{15}=9.869, p<.001\right)$ 모두 95\% 신뢰수준에서 통계적으로 유의한 것으로 나타났다. 즉, 정상

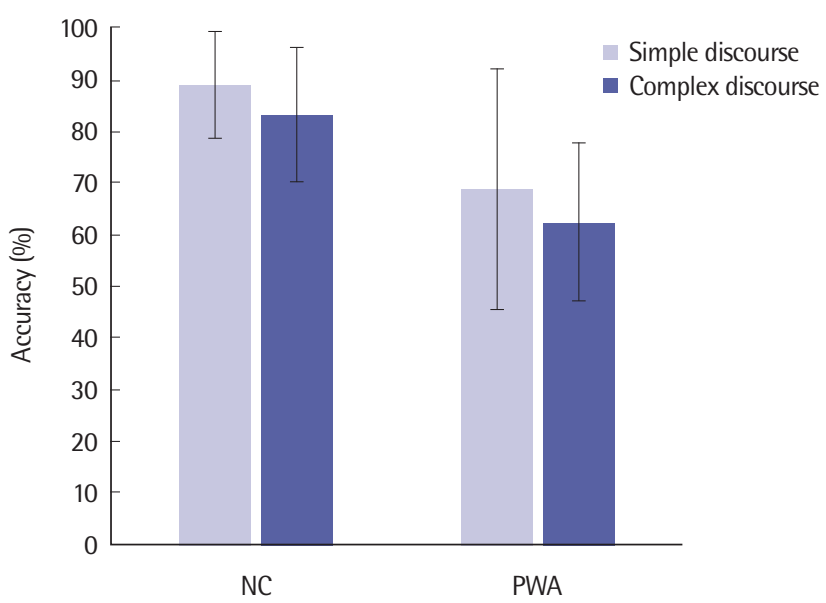

Figure 3. Comparisons between simple and complex discourse in the last sentence for both groups. $\mathrm{NC}=$ normal controls; $\mathrm{PWA}=$ people with aphasia. Error bar indicates standard deviation.

Table 1. Correlation coefficient among tasks in people with aphasia

\begin{tabular}{|c|c|c|c|c|c|c|c|c|c|}
\hline & $A C \_T$ & AC_S & AC_W & Active & Passive & Conjoined & Embedded & $\begin{array}{l}\text { Simple discourse_ } \\
\text { last sentence }\end{array}$ & $\begin{array}{l}\text { Complex discourse_ } \\
\text { last sentence }\end{array}$ \\
\hline $\mathrm{A} 0$ & $.869^{* *}$ & $.829^{* *}$ & $.691^{* *}$ & $.543^{*}$ & $.549 *$ & $.665^{* *}$ & .464 & $.734^{* *}$ & .510 \\
\hline AC_T & - & $.958^{* *}$ & $.786^{* *}$ & .388 & .372 & $.674^{* *}$ & $.613^{*}$ & $.730^{* *}$ & .531 \\
\hline AC_S & & - & $.576^{*}$ & .379 & .347 & $.587^{*}$ & $.537^{*}$ & $.631^{*}$ & .409 \\
\hline AC_W & & & - & .289 & .311 & $.656^{*}$ & $.591^{*}$ & $.723^{* *}$ & $.633^{*}$ \\
\hline Active & & & & - & $.554^{*}$ & .218 & .293 & .400 & .259 \\
\hline Passive & & & & & - & .508 & -.030 & .416 & .386 \\
\hline Embedded & & & & & & - & .282 & $.708^{* *}$ & $.737^{* *}$ \\
\hline Simple discourse_last sentence & & & & & & & - & .458 & .475 \\
\hline Simple discourse_last sentence & & & & & & & & - & $.796^{* *}$ \\
\hline
\end{tabular}

$A Q=$ aphasia quotient; $A C \_T=$ total score of Auditory Comprehension Sections (K-WAB Subtests); $A C \_S=$ sentence comprehension score of Auditory Comprehension Sections (K-WAB Subtests); $A C \_W=$ word comprehension score of Auditory Comprehension Sections (K-WAB Subtests).

${ }^{*} p<.05,{ }^{* *} p<.01$. 
집단의 마지막 문장이해에 대한 정반응률은 우연 수준보다 유의하 게 높은 것으로 나타났다.

\section{통사적 복잡성에 따른 담화 속 문장이해 정반응률과 실어증 중증도 및 표준화 검사 내 이해 하위검사 점수와의 상관관계 분석}

통사적 복잡성에 따른 담화 속 문장이해 정반응률과 실어증 중 증도(aphasia quotient, $\mathrm{AQ}$ ) 및 표준화 검사 내 이해 하위검사 점수 와의 상관관계를 확인하기 위해 Pearson 상관계수를 산출하였다 (Table 1).

실어증 환자의 담화 속 문장이해 정반응률과 실어증 중증도 및 표준화 검사 내 이해 하위검사 점수 간의 상관관계를 분석한 결과, 실어증 중증도는 통사적 복잡성에 따른 담화 속 능동문 $(r=.543$, $p<.05)$, 피동문 $(r=.549, p<.05)$, 접속문 $(r=.665, p<.01)$, 단순한 담화 내 마지막 문장 $(r=.734, p<.01)$ 의 정반응률과 유의한 상관을 보였다. 표준화검사 내 이해 하위검사(K-WAB의 알아듣기 영역) 전 체 점수는 통사적 복잡성에 따른 담화 속 접속문 $(r=.674, p<.01)$, 내포문 $(r=.613, p<.05)$, 단순한 담화 내 마지막 문장 $(r=.730, p<.01)$ 의 정반응률과 유의한 상관을 보였으며, 표준화 검사 내 이해 하위 검사의 문장이해(K-WAB의 알아듣기 영역 중 예/아니오, 명령이행) 점수도 마찬가지로 통사적 복잡성에 따른 담화 속 접속문 $(r=.587$, $p<.05)$, 내포문 $(r=.537, p<.05)$, 단순한 담화 내 마지막 문장 $(r=.631$, $p<.05)$ 의 정반응률과 유의한 상관을 보였다. 또한, 표준화 검사 내 이해 하위검사의 단어이해(K-WAB의 알아듣기 영역 중 청각적 낱말 인지 $)$ 점수는 통사적 복잡성에 따른 담화속 접속문 $(r=.656, p<.05)$, 내포문 $(r=.591, p<.05)$, 단순한 담화 내마지막 문장 $(r=.723, p<.01)$, 복잡한 담화 내 마지막 문장 $(r=.633, p<.05)$ 의 정반응률과 유의한 정적상관을 보였다.

\section{논의 및 결론}

본 연구의 목적은 담화 수준에서도 실어증 환자가 문장이해의 결함을 보이는지 살펴보는 것이었다. 그 결과, 첫째, 실어증 환자와 정상 성인 간 담화 내 단문이해 능력에 차이가 있었으며, 정상 성인 보다 실어증 환자가 담화 내 단문이해에 더 어려움을 보인다는 것 을 알 수 있었다. 이는 의미 가역적인 문장을 해석하는데 실어증 환 자들이 어려움을 보인다고 보고한 국외 및 국내 선행연구들과 맥락 을 같이 한다(Caplan et al., 2007; Caramazza \& Zurif, 1976; Caramazza, Capasso, Capitani, \& Miceli, 2005; Friedmann, Reznick, Dolinski-Nuger, \& Soboleva, 2010; Kim, 2010; Kim JH, 2002; Kim
YJ, 2002; Law \& Leung, 2000; Nam et al., 1999; O’Grady \& Lee, 2005; Son, 2004; Su, Lee, \& Chung, 2007; Wassenaar \& Hagoort, 2007; Yoon, 2002). 즉, 본 연구는 실어증 환자의 단문이해 능력의 결함이 문장 수준에서뿐만 아니라 담화 내 문장 수준에서도 나타 남을 시사한다.

그러나 담화 내 문장의 통사적 복잡성에 따른 단문 이해에 대한 주효과는 통계적으로 유의하지 않았으며, 담화 내 문장의 통사적 복잡성에 따른 단문에서 집단 간 상호작용 효과 또한 유의하지 않 았다. 이는 어순을 달리하여 통사적 복잡성에 변화를 준 담화를 실 어증 환자에게 적용하였더니 담화 내 문장이해에 있어 통사적 복 잡성의 영향을 받지 않았다는 Caplan과 Evans (1990)의 연구 결과 와 일치한다. Caplan과 Evans (1990)는 실어증 환자의 통사구조 이 해 결함이 담화를 이해하는데 있어 방해 요인이 될 수는 있으나, 통 사구조 이해 결함만으로 실어증 환자의 담화이해 어려움을 설명할 수는 없다고 밝혔다. 또한, 상대적으로 통사구조가 더 복잡한 간접 화법과 덜 복잡한 직접 화법 간 이해 정확도 차이 비교에서 실어증 환자에게 유의한 결과가 나타나지 않았다는 Groenewold, Bastiaanse, Nickels와 Huiskes (2014)의 연구와 뇌손상 환자의 담화이해 능력을 알아보기 위해 실시한 연구에서 실어증 환자의 경우, 담화 내 언급된 명시적 정보보다 암시적 정보에 대한 정반응률이 더 높 았다는 Ferstl, Walther, Guthke와 von Cramon (2005)의 연구와도 연결 지어볼 수 있다. Groenewold 등(2014)은 문맥이 있는 담화 상 황에서 문법적으로 복잡한 통사구조의 담화보다 단순한 통사구조 의 담화를 실어증 환자들이 더 쉽게 이해할 것이라는 통념이 항상 유효한 것은 아니라고 하였다. 즉, 각 나라의 언어가 가지는 특수성 에 따라 그 결과가 다르게 나타날 수 있으며, 담화이해 상황에서 통 사구조를 제외한 요인들의 영향도 배제할 수 없음을 밝히고 있다. 위와 같은 연구 결과들은 실어증 환자가 담화 내 표면적으로 드러 난 문장 수준보다 오히려 문맥적인 힌트나 일반적인 배경 지식, 상 황적인 표상에 더 의존할 수도 있다는 가능성을 제기한다. 즉, 본 연 구 결과에서 통사적 복잡성을 달리한 문장 유형 간 이해의 차이가 없었던 것은 담화이해를 결정짓는 많은 요인들 중 담화를 구성하 는 문장의 통사적 복잡성 하나만 통제하였더니, 통계적으로 유효 할 만한 결과가 나오지 않았다고 해석해 볼 수 있다. 더불어 실어증 환자들이 담화를 이해할 때, 담화를 구성하는 문장의 수준 보다 오 히려 담화의 상황, 맥락적인 부분에 더 의존하는 것이 아닌가에 대 한 가능성이 제기된다. Groenewold, Bastiaanse와 Huiskes (2013) 는 직접 대화에서 실어증 환자의 비교적 손상되지 않은 화용적 측 면, 맥락적 측면, 동작, 운율 등을 파악할 수 있는 능력이 담화이해 에 도움이 될 것이라고 밝히고 있다. 즉, 실어증 환자가 언어적 결함 
을 가지고 있음에도 불구하고 담화는 문장의 상위 구조로 여러 층 위의 요소를 포함하고 있기 때문에 그 중 손상되지 않은 요소가 실 어증 환자의 담화이해에 단서를 제공할 수도 있다는 가능성을 부 여한다.

그럼에도 불구하고 이와 같은 결론을 단정 짓기에는 다소 무리가 따르는데, 실어증 환자와 정상 집단의 단문이해 과제에 대한 수행 력이 우연 수준 이상인지 알아본 결과, 정상 집단의 경우 모두 우연 수준 이상의 정반응률을 보였으나, 실어증 환자의 경우 우연 수준 과 유의한 차이가 없었다. 즉, 실어증 환자의 평균 정반응률이 우연 수준과 유의한 차이가 없었던 것은 실어증 환자가 담화 내 단문에 대한 이해가 전혀 없음에도 불구하고 추측하여 정반응을 할 수 있 는 확률이 존재했음을 의미한다. 따라서 본 연구 과제에 대한 실어 증 환자의 담화 내 단문이해 능력의 한계를 고려할 필요가 있다. 또 한, 본 연구에서는 담화 전체를 대상자에게 제시한 이후에 담화에 포함된 문장의 이해도를 평가하였기 때문에 대상자가 담화 맥락을 활용하였는지, 각 문장의 의미에 의존하였는지에 대한 판단이 모 호할 수 있다.

둘째, 정상 성인 보다 실어증 환자의 담화 내 복문이해 능력이 상 대적으로 낮음을 알 수 있다. 이는 실어증 환자를 대상으로 단문 및 복문에 대한 이해 정확도를 분석한 결과, 그 정확도가 단문에서뿐만 아니라 복문에서도 정상 성인에 비해 현저하게 낮음을 밝힌 J. Y. $\operatorname{Kim}$ (2015)의 연구와 실어증 환자의 통사적 처리 능력 결함으로 인 해 복문 중에서도 관계절 문장이해 과제의 수행력이 떨어지는 것으 로 나타난 Y. J. Kim (2002)의 연구 결과와 일치한다. 또한, 담화 내 단문과 복문을 삽입하여 실어증 환자와 정상 성인 간 이해 정확도 를 비교한 결과, 단문뿐 아니라 복문에서도 실어증 환자의 이해 정 확도가 더 낮았음을 보여준 Levy 등(2012)의 결과와 맥락을 같이 한다. 즉, 본 연구는 실어증 환자의 복문이해 능력의 결함이 문장 수 준에서뿐만 아니라 담화 내 문장 수준에서도 나타남을 시사한다.

하지만 담화 내 접속문과 내포문에서의 정반응률은 유의한 차 이가 없었으며, 담화 내 복문 유형에 따른 집단 간 유의한 차이가 없 었다. 통계적으로 유의한 차이는 나타나지 않았으나, 기술통계 결 과, 평균 점수를 살펴보면 정상 집단은 접속문(76.67), 내포문(76.67) 로 나타났으며, 실어증 환자는 접속문(66.07), 내포문(58.04)로 나 타났다. 즉, 정상 집단은 복문 유형에 따른 문장이해 정반응률의 평 균 점수가 비슷한 수준임에 반하여, 실어증 환자는 복문 유형에 따 라 점수에 차이가 나는 것을 알 수 있다. 이와 같은 기술통계 결과 를 바탕으로 통사적 복잡성을 달리한 복문 유형에 따른 집단 간 차 이가 있었음에도 불구하고 상호작용 효과가 유의하게 나타나지 않 은 것은 제한된 대상자 수에 기인한 것으로 생각된다.
복문이해 과제에 대한 수행력이 우연 수준 이상인지 알아보았 고, 그 결과, 정상 집단의 경우 접속문과 내포문 모두 우연 수준 이 상의 정반응률을 보였다. 실어증 환자의 경우, 접속문은 우연 수준 이상의 정반응률을 보였으나, 내포문은 우연 수준과 유의한 차이 가 나타나지 않았다. 이를 단문에서의 정반응률과 연결지어보면 능동문, 피동문, 내포문에서는 우연 수준과 유의한 차이가 나타나 지 않았으나, 접속문에서는 우연 수준보다 높은 정반응률을 보였 음을 알 수 있다. 피동문과 내포문의 경우, 어순의 위치 변화와 더 불어 의미역의 관계가 복잡해지기 때문에 통사적 복잡성이 두드러 지는 문장 유형이라고 할 수 있다. 따라서 실어증 환자의 경우, 담화 내 문장이해에 있어 처리 용량의 부담으로 인해 우연 수준 정도의 수행력을 보인 것으로 해석이 가능하다.

셋째, 통사적으로 복잡한 문장이 담화에 삽입됨으로 담화 전체 이해에 영향을 미치는지 알아보기 위해 담화 내 마지막 문장이해 정반응률에 실어증 환자와 정상 집단 간 차이가 있는지 살펴보았 다. 그 결과, 정상 집단의 정반응률이 실어증 환자보다 유의하게 더 높은 것으로 나타났다. 이는 실어증 환자와 정상 성인의 듣기 및 읽 기 이해력을 비교해보고자 실시한 L. Y. Kim (2015)의 연구에서 집 단 간 담화 수준의 평가에서 이해 정확도에 차이를 보였던 연구 결 과와 일치한다. 즉, 본 연구 결과는 정상 성인과 비교하였을 때, 실어 증 환자가 담화 내 문장이해에 어려움을 보일 뿐만 아니라 문맥 상 황이 반영되는 담화 전체에 있어서도 상대적 이해 결함을 보인다는 점을 시사한다.

또한, 통사적으로 단순한 담화에서의 정반응률이 복잡한 담화 에서 보다 유의하게 더 높은 것으로 나타났다. 이를 위해 각 담화의 구조를 살펴보면 단순한 담화의 경우 능동문과 접속문이 삽입되어 있고, 복잡한 담화의 경우 피동문과 내포문이 삽입되어 있다. 즉, 복잡한 담화에 상대적으로 통사적 복잡성이 높은 문장들이 삽입 되어 있음을 알 수 있다. 이는 실어증 환자로 하여금 전체 담화이해 도출 시, 처리 용량의 부담을 가중시킨다. 따라서 담화 내 통사적으 로 복잡한 문장이 두 개가 삽입됨으로 처리 용량에 대한 부담이 누 적되어 맨 뒤에 나온 마지막 문장에 대한 이해가 방해를 받았던 것 이다. 즉, 처리 과정의 용량 결함으로 인해 단순한 담화의 마지막 문 장에 대한 정반응률이 복잡한 담화보다 유의하게 높게 나타났던 것이다.

담화 내 문장의 통사적 복잡성에 따른 마지막 문장이해 정반응 률과 집단 간 상호작용은 유의하지 않았는데, 이는 실어증 환자와 정상 집단 모두 복잡한 담화에서의 정반응률이 단순한 담화에서 보다 상대적으로 낮음에 기인한다. 즉, 실어증 환자와 정상 집단 모 두 복잡한 담화에서 담화 이해의 처리 용량에 대한 부담이 증가하 
여 유의한 상호작용 효과가 나타나지 않은 것으로 생각된다.

넷째, 실어증 환자의 실어증 중증도 및 표준화 검사 내 이해 하위 검사 점수가 통사적 복잡성에 따른 담화 속 문장이해 정반응률과 연관이 있는지 알아보기 위해 상관관계를 확인하였다.

통사적 복잡성에 따른 담화 속 문장이해 정반응률과 실어증 중 증도의 상관관계를 확인한 결과, 실어증 중증도와 통사적 복잡성 에 따른 담화 속 전반적인 문장이해 간 유의한 상관관계가 있는 것 으로 보인다. 실어증 중증도는 통사적 복잡성에 따른 담화 속 능동 문, 피동문, 접속문, 단순한 담화 내 마지막 문장의 정반응률과 유 의한 상관을 보였으며, 그 중에서도 단순한 담화 내 마지막 문장의 정반응률은 실어증 중증도를 가장 잘 예측하는 변수로 나타났다. 통사적 복잡성에 따른 담화 속 문장이해 정반응률과 표준화 검사 내 이해 하위검사 점수 간 상관관계를 확인한 결과, K-WAB의 알아 듣기 전체 점수, $\mathrm{K}-\mathrm{WAB}$ 의 알아듣기 중 문장이해 점수, $\mathrm{K}-\mathrm{WAB}$ 의 알아듣기 중 단어이해 점수 모두 변수 간 대체로 유의한 상관관계 가 나타났다. 그러나 실어증 중증도와는 달리 담화 속 단문보다는 복문에서 상관관계가 높은 것으로 나타났다. 따라서 K-WAB의 이 해 하위검사 문항들은 본 연구 과제의 담화 속 문장 유형의 복잡성 과 연관이 높은 것으로 보인다. 즉, $\mathrm{K}-\mathrm{WAB}$ 의 이해 하위검사 문항 들은 담화를 이루는 문장의 통사적 복잡성 보다는 담화를 이루는 문장 유형의 복잡성과 연관이 깊다는 점에서 흥미로운 보고라 할 수 있겠다.

연구자들은 연구 결과를 통해 실어증 환자의 담화 수준에서의 언어이해 능력 평가가 중요하다고 시사하며, 언어이해 양상을 궁극 적으로 알아보기 위해서는 담화 수준에서의 고찰이 필수적이라고 지적하고 있다. 실어증 환자의 담화이해 능력에 대한 관심이 증가 하는 가운데, 본 연구 결과는 실어증 환자의 담화수준에서의 문장 이해 양상을 살펴볼 수 있는 기초 자료를 제공한다는 점에서 임상 적 의의가 있다. 또한, 더 나아가 실어증 환자를 대상으로 담화를 활 용한 중재 프로토콜을 만드는 데에도 기초자료로 사용될 수 있다. 그러나 담화 내 문장이해 판단과제에 대한 실어증 환자의 정반응 률이 대부분 우연 수준에 그쳤으며, 실험시간 등의 제약으로 인해 구체적인 데이터 수집의 한계가 있었던 것으로 생각된다. 따라서 과 제의 난이도를 통제하고, 반응시간 등 보다 구체적인 수치를 더한 후속연구가 필요하다.

\section{REFERENCES}

Baik, K. S. (2004). Analyses of semantic contents and organization of narratives in right brain damaged patients. Korean Journal of Communication
Disorders, 9, 72-101.

Beretta, A., Piñango, M., Patterson, J., \& Harford, C. (1999). Recruiting comparative crosslinguistic evidence to address competing accounts of agrammatic aphasia. Brain and Language, 67, 149-168.

Brookshire, R. H., \& Nicholas, L. E. (1993). The discourse comprehension test. Tucson, AZ: Communication Skill Builders.

Brookshire, R. H., \& Nicholas, L. E. (2008). Discourse comprehension test-revised. Sedona, AZ: BRK Publishers.

Burchert, F., De Bleser, R., \& Sonntag, K. (2003). Does morphology make the difference? Agrammatic sentence comprehension in German. Brain and Language, 87, 323-342.

Byun, J., Shin, J. C., Kim, D. Y., \& Kim, H. (2009). Characteristics of story grammar in fluent aphasic patients. Korean Journal of Communication Disorders, $14,160-172$.

Caplan, D., \& Evans, K. L. (1990). The effects of syntactic structure on discourse comprehension in patients with parsing impairments. Brain and Language, 39, 206-234.

Caplan, D., \& Futter, C. (1986). Assignment of thematic roles to nouns in sentence comprehension by an agrammatic patient. Brain and Language, 27, 117-134.

Caplan, D., \& Waters, G. S. (1999). Verbal working memory and sentence comprehension. Behavioral and Brain Sciences, 22, 77-94.

Caplan, D., Waters, G., DeDe, G., Michaud, J., \& Reddy, A. (2007). A study of syntactic processing in aphasia. I: Behavioral (psycholinguistic) aspects. Brain and Language, 101, 103-150.

Caramazza, A., \& Zurif, E. B. (1976). Dissociation of algorithmic and heuristic processes in language comprehension: evidence from aphasia. Brain and Language, 3, 572-582.

Caramazza, A., Capasso, R., Capitani, E., \& Miceli, G. (2005). Patterns of comprehension performance in agrammatic Broca's aphasia: a test of the trace deletion hypothesis. Brain and Language, 94, 43-53.

Carpenter, P. A., Miyake, A., \& Just, M. A. (1994). Working memory constraints in comprehension: evidence from individual differences, aphasia, and aging. In M. A. Gernsbacher (Ed.), Handbook of psycholinguistics (pp. 10751122). San Diego, CA: Academic Press.

Choi, S. Y. (2012). Comprehension of active and passive sentences in Korean aphasics: evidence for processing deficit hypothesis. Korean Journal of Communication Disorders, 17, 322-337.

Ferstl, E. C., Walther, K., Guthke, T., \& von Cramon, D. Y. (2005). Assessment of story comprehension deficits after brain damage. Journal of Clinical and 
Experimental Neuropsychology, 27, 367-384.

Friedmann, N., Reznick, J., Dolinski-Nuger, D., \& Soboleva, K. (2010). Comprehension and production of movement-derived sentences by Russian speakers with agrammatic aphasia. Journal of Neurolinguistics, 23, 44-65.

Goodglass, H., \& Hunt, J. (1958). Grammatical complexity and aphasic speech. Word, 14, 197-207.

Grodzinsky, Y. (1995). A restrictive theory of agrammatic comprehension. Brain and Language, 50, 27-51.

Groenewold, R., Bastiaanse, R., \& Huiskes, M. (2013). Direct speech constructions in aphasic Dutch narratives. Aphasiology, 27, 546-567.

Groenewold, R., Bastiaanse, R., Nickels, L., \& Huiskes, M. (2014). Perceived liveliness and speech comprehensibility in aphasia: the effects of direct speech in auditory narratives. International Journal of Language \& Communication Disorders, 49, 486-497.

Hagiwara, H. (1995). The breakdown of functional categories and the economy of derivation. Brain and Language, 50, 92-116.

Hwang, J. H. (2002). Processing of semantic particles in Broca's aphasic patients' sentence comprehension (Master's thesis). Yonsei University, Seoul, Korea.

Hwang, M. (2002). Sentence comprehension of Korean-speaking adults with Broca's aphasia. Korean Journal of Communication Disorders, 7, 65-85.

Kang, Y. (2006). A normative study of the Korean-Mini Mental State Examination (K-MMSE) in the elderly. Korean Journal of Psychology: General, 25, 1-12.

Kang, Y. W., Chin, J. H., Na, D. L., Lee, J. H., \& Park, J. S. (2000). A normative study of the Korean version of Controlled Oral Word Association Test (COWAT) in the elderly. Korean Journal of Clinical Psychology, 19, 385392.

Kim, H. H., \& Na, D. L. (2001). Paradise-Korean version-Western Aphasia Battery $(K-W A B)$. Seoul: Paradise Welfare Foundation.

Kim, H. J., Yu, Y. J., \& Jeong, O. R. (2004). Discourse Analyses on scene descriptions by right-hemisphere-damaged and non-brain-damaged adults. Journal of Speech \& Hearing Disorders, 13, 169-178.

Kim, J. H. (2002). Effects of canonical word order to Korean sentence comprehension in Broca's aphasic patients (Master's thesis). Yonsei University, Seoul, Korea.

Kim, J. Y. (2015). Comprehension of active and passive sentences in nonfluent aphasia (Doctoral dissertation). Yonsei University, Seoul, Korea.

Kim, L. Y. (2015). Listening and reading comprehension of mild aphasia adults (Master's thesis). Dankook University, Yongin, Korea.

Kim, M. J. (2007). Discourse comprehension and theory of mind in right hemi- sphere-damaged patient (Master's thesis). Dankook University, Yongin, Korea.

Kim, M. Y. (2008). The comprehension of proverb in patients with right-hemisphere damaged: the role of familiarity and context (Master's thesis). Ewha Womans University, Seoul, Korea.

Kim, Y. J. (2002). Relative clause sentence comprehension of Broca's aphasics (Master's thesis). Yonsei University, Seoul.

Kim, A. H. (2010). Comprehension of Wh-questions according to the severity of Broca's aphasia: who, what(subject/object) (Master's thesis). Dankook University, Yongin, Korea.

Law, S. P., \& Leung, M. T. (2000). Sentence processing deficits in two Cantonese aphasic patients. Brain and Language, 72, 310-342.

Lee, D. J., Yeon, J. H., Hwang, I. B., \& Lee, S. G. (2010). KKMA: a tool for utilizing Sejong corpus based on relational database. Journal of KIISE: Computing Practices and Letters, 16, 1046-1050.

Lee, J. S. (2001). Hanguk-eo-ui sije-wa sang. Seoul: Kookhak jalyowon.

Lee, M., \& Thompson, C. K. (2004). Agrammatic aphasic production and comprehension of unaccusative verbs in sentence contexts. Journal of Neurolinguistics, 17, 315-330.

Levy, J., Hoover, E., Waters, G., Kiran, S., Caplan, D., Berardino, A., \& Sandberg, C. (2012). Effects of syntactic complexity, semantic reversibility, and explicitness on discourse comprehension in persons with aphasia and in healthy controls. American Journal of Speech-Language Pathology, 21, S154S165.

McNeil, M. R., \& Pratt, S. R. (2001). Defining aphasia: some theoretical and clinical implications of operating from a formal definition. Aphasiology, 15, 901-911.

Myers, E. B., \& Blumstein, S. E. (2005). Selectional restriction and semantic priming effects in normals and Broca's aphasics. Journal of Neurolinguistics, 18, 277-296.

Nam, K., Yim, C., Jung, J., Kim, D., \& Pyun, S. (1999). Agrammatism in Broca's aphasia: dissociation of sentence production and comprehension. Korean Journal of Psychology: General, 18, 49-64.

Nicholas, L. E., \& Brookshire, R. H. (1995). Comprehension of spoken narrative discourse by adults with aphasia, right-hemisphere brain damage, or traumatic brain injury. American Journal of Speech-Language Pathology, 4, 69-81.

O’Grady, W., \& Lee, M. (2005). A mapping theory of agrammatic comprehension deficits. Brain and Language, 92, 91-100.

Schwartz, M. F., Saffran, E. M., \& Marin, O. S. (1980). The word order prob- 
Hye Lim Kim, et al. • Syntactic Complexity in Discourse for Aphasia

lem in agrammatism. I: Comprehension. Brain and Language, 10, 249-262.

Son, H. M. (2004). Comprehension of reversible passive sentence in Koreanspeaking adults with Broca's aphasia (Master's thesis). Dankook University, Yongin, Korea.

Su, Y. C., Lee, S. E., \& Chung, Y. M. (2007). Asyntactic thematic role assignment by Mandarin aphasics: a test of the trace-deletion hypothesis and the double dependency hypothesis. Brain and Language, 101, 1-18.

Wassenaar, M., \& Hagoort, P. (2007). Thematic role assignment in patients with Broca's aphasia: sentence-picture matching electrified. Neuropsycho- logia, 45, 716-740.

Woo, I. H. (1997). Ulimal pidong yeongu. Seoul: Hankookmunhwasa.

Yang, M. J. (2000). Analysis of discourse abilities in Broca's aphasic patients: the considerations of coherence (Master's thesis). Yonsei University, Seoul, Korea.

Yoon, J., \& Kim, Y. T. (2002). The category specificity in Korean Broca’s aphasic patients: the impairment of verb comprehension. Korean Journal of Communication Disorders, 7, 39-54. 
Appendix 1. 실어증 환자 정보

\begin{tabular}{|c|c|c|c|c|c|c|c|c|c|c|c|}
\hline \multirow[b]{2}{*}{ 번호 } & \multirow[b]{2}{*}{ 연령 } & \multirow[b]{2}{*}{ 성별 } & \multirow{2}{*}{$\begin{array}{l}\text { 교육 } \\
\text { 년수 }\end{array}$} & \multirow{2}{*}{$\begin{array}{l}\text { 발병 후 } \\
\text { 개월 수 }\end{array}$} & \multirow[b]{2}{*}{ 병인 } & \multicolumn{5}{|c|}{$K-W A B$} & \multirow{2}{*}{$\begin{array}{l}\text { 실어증 } \\
\text { 유형 }\end{array}$} \\
\hline & & & & & & $\begin{array}{c}\text { 실어증 } \\
\text { 지수(AQ) }\end{array}$ & 유창성 & 알아듣기 & 따라말하기 & 이름대기 & \\
\hline 1 & 45 & $\mathrm{M}$ & 9 & 8 & Lt. BG ICH & 62.2 & 6 & 7.2 & 3.9 & 5 & Conduction \\
\hline 2 & 19 & $\mathrm{~F}$ & 12 & 2 & Lt. ICH & 89.1 & 9 & 8.95 & 7 & 9.6 & Anomic \\
\hline 3 & 60 & $\mathrm{M}$ & 12 & 4 & Lt. MCA & 75.8 & 6 & 7.6 & 8.6 & 7.7 & Anomic \\
\hline 4 & 52 & M & 12 & 19 & Lt. ICA & 55.3 & 4 & 6.85 & 7 & 4.8 & Broca \\
\hline 5 & 46 & M & 12 & 12 & Lt. ICH & 70.3 & 7 & 8.65 & 4.9 & 7.6 & Conduction \\
\hline 6 & 56 & M & 9 & 20 & Lt. BG ICH & 78.4 & 6 & 7.7 & 9.1 & 8.4 & Anomic \\
\hline 7 & 60 & $\mathrm{~F}$ & 6 & 23 & Lt. ICH & 48 & 9 & 5.9 & 4.1 & 5 & Broca \\
\hline 8 & 18 & M & 10 & 36 & Lt. T-SDH & 91.4 & 9 & 9.6 & 10 & 9.1 & Anomic \\
\hline 9 & 69 & M & 12 & 3 & Lt. pons infarction & 90.7 & 9 & 9.15 & 9.5 & 8.7 & Anomic \\
\hline 10 & 56 & M & 9 & 9 & Both pons infarction & 58.3 & 4 & 7.35 & 6 & 6.8 & Broca \\
\hline 11 & 50 & $\mathrm{~F}$ & 12 & 10 & Lt. SAH/ICH & 89.1 & 9 & 9.05 & 9.8 & 7.7 & Anomic \\
\hline 12 & 35 & $\mathrm{~F}$ & 14 & 82 & Lt. BG ICH & 44.5 & 4 & 7.35 & 2.4 & 3.5 & Broca \\
\hline 13 & 59 & $\mathrm{~F}$ & 9 & 5 & Lt. brain tumor & 76.8 & 8 & 8.2 & 7.6 & 6.6 & Anomic \\
\hline 14 & 48 & $\mathrm{~F}$ & 12 & 5 & Lt. parietal lobe infarction & 86.1 & 9 & 8.25 & 7.7 & 9.1 & Anomic \\
\hline
\end{tabular}

K-WAB=Korean version of Western Aphasia Battery (Kim \& Na, 2001); $A Q=$ aphasia quotient; $B G=$ basal ganglia; ICH=intracerebral hemorrhage; $M C A=m i d d l e$ cerebral artery; ICA=internal carotid artery; T-SDH=traumatic subdural hematoma.

Appendix 2. 정상 집단 정보

\begin{tabular}{|c|c|c|c|c|}
\hline 번호 & 연령 & 성별 & 교육년수 & K-MMSE \\
\hline 1 & 59 & $\mathrm{~F}$ & 9 & 28 \\
\hline 2 & 58 & $\mathrm{~F}$ & 12 & 27 \\
\hline 3 & 52 & $F$ & 12 & 30 \\
\hline 4 & 54 & M & 12 & 28 \\
\hline 5 & 54 & $\mathrm{~F}$ & 12 & 29 \\
\hline 6 & 52 & $\mathrm{~F}$ & 9 & 30 \\
\hline 7 & 74 & M & 6 & 29 \\
\hline 8 & 63 & M & 10 & 29 \\
\hline 9 & 68 & M & 12 & 30 \\
\hline 10 & 64 & M & 9 & 27 \\
\hline 11 & 52 & $\mathrm{~F}$ & 12 & 29 \\
\hline 12 & 18 & $M$ & 14 & 27 \\
\hline 13 & 24 & $F$ & 9 & 30 \\
\hline 14 & 24 & M & 12 & 30 \\
\hline 15 & 24 & $\mathrm{~F}$ & 14 & 30 \\
\hline
\end{tabular}

K-MMSE=Korean-Mini Mental Status Examination (Kang, 2006). 
Appendix 3. 담화의 예시

단순한 문장구조가 삽입된 담화: 단순한 담화

이모가 계단을 내려오면서 미끄러졌다.

계단 아래에는 조카가 있었다.

이모가 조카를 찼다. (능동문)

조카는 울었다.

이모는 할머니를 불렀고, 할머니는 조카를 안았다.(접속문)

할머니는 이모를 혼냈다.

복잡한 문장구조가 삽입된 담화: 복잡한 담화

이모가 계단을 내려오면서 미끄러졌다.

계단 아래에는 조카가 있었다.

조카가 이모에게 차였다.(피동문)

조카는 울었다.

이모가 부른 할머니가 조카를 안았다.(내포문)

할머니는 이모를 혼냈다.

Appendix 4. 판단문장의 예시

\begin{tabular}{llll}
\hline & & 목표문장 & 판단문장 \\
\hline 단문 & 능동문 & 이모가 조카를 찼다. & 이모가 조카를 찼다. (예 / 아니오) \\
& 피동문 & 조카가 이모에게 차였다. & 이모가 조카를 찼다. (예 / 아니오) \\
복문 & 접속문 & 이모는 할머니를 불렀고, 할머니는 조카를 안았다. & 할머니가 이모를 불렀다. (예 / 아니오) \\
& 내포문 & 이모가 부른 할머니가 조카를 안았다. & 할머니가 이모를 불렀다. (예 / 아니오) \\
마지막 문장 & & 할머니는 이모를 혼냈다. & 할머니는 이모를 혼냈다. (예 / 아니오) \\
\hline
\end{tabular}




\section{국문초록}

\section{실어증 환자의 통사적 복잡성에 따른 담화 속 문장이해 능력 비교}

\section{김혜림 · 성지은}

이화여자대학교 대학원 언어병리학과

배경 및 목적: 실어증 환자의 언어이해 결함을 담화수준에서 알아보기 위해 통사적 복잡성을 달리한 담화 내 문장이해 능력을 평가하 여 집단 간 차이를 알아보고자 한다. 방법: 연령과 교육년수를 일치시킨 실어증 환자 14 명과 정상 집단 15 명을 대상으로 통사적 복잡성 이 다른 문장이 포함된 단순한 담화(능동문 및 접속문 삽입)와 복잡한 담화(피동문 및 내포문 삽입)를 이해한 후, 제시되는 판단문장 의 정반응률을 분석하였다. 통계처리는 이원혼합분산분석을 사용하였다. 결과: 담화 내 통사적 복잡성에 따른 단문이해(능동문 및 피 동문)및 복문이해(접속문 및 내포문) 과제에서 모두 실어증 환자군이 정상군에 비해 낮은 수행력을 보였다. 단문과 복문 유형 모두에서 통사적 복잡성과 집단 간 상호작용 효과는 유의하지 않았다. 담화 내 마지막 문장이해에서 실어증 환자의 경우 통사적으로 단순한 담 화 및 복잡한 담화에서 모두 정상 집단에 비해 유의하게 낮은 정반응률을 보였으나, 담화 유형에 따른 집단 간 상호작용은 유의하지 않 았다. 논의 및 결론: 실어증 환자의 경우 통사적으로 단순한 문장으로 구성된 담화 내용의 이해에 비해 복잡한 통사구조로 이루어진 담화이해에서 더 큰 어려움을 보였다. 또한, 실어증 중증도와 전반적인 담화이해 간 유의한 상관관계가 있는 것으로 나타났다. 본 연구 는 실어증 환자의 담화수준에서의 문장이해 양상을 살펴볼수 있는 기초 자료를 제공한다는 점에서 임상적 의의가 있다.

핵심어: 실어증, 담화, 통사적 복잡성, 문장이해능력

\section{참고문헌}

강연욱(2006). K-MMSE (Korean-Mini Mental State Examination)의 노인 규준 연구. 한국심리학회지: 일반, 25, 1-12.

강연욱, 진주희, 나덕렬, 이정희, 박재설(2000). 통제 단어 연상 검사 (Controlled Oral Word Association Test) 의 노인 규준 연구. 한국심리학회지: 임

상, 19, 385-392.

김난영(2015). 경도 실어증 환자와 정상성인의 듣기 및 읽기이해 능력 비교. 단국대학교대학원 석사학위논문.

김민영(2008). 우반구 뇌손상 환자의 속담이해능력: 속담의 친숙성과 문맥의 제시 여부를 중심으로. 이화여자대학교대학원 석사학위논문.

김민정(2007). 비우세 반구(우반구) 손상 환자의 담화 이해와마음이론. 단국대학교대학원 석사학위논문.

김아현(2010). 브로카 실어증 환자의 장애 정도에 따른 의문문 이해: ‘누구, '무엇'을 중심으로. 단국대학교대학원 석사학위논문.

김윤주(2002). 브로카 실어증 환자의 관계절 문장 이해. 연세대학교대학원 석사학위논문.

김정연(2015). 비유창실어증 환자의 능동문과 피동문 이해특성. 연세대학교대학원 박사학위논문.

김정하(2002). 브로카 실어증 환자들의 한국어 문장 이해에서 규범 어순의 영향. 연세대학교대학원 석사학위논문.

김향희, 나덕렬(2001). 파라다이스-한국판-웨스턴실어증검사. 서울: 파라다이스 복지재단.

김효정, 유영진, 정옥란. (2004). 우반구 손상자와 정상 성인의 그림 설명하기 담화의 특성 비교. 언어치료연구, 13, 169-178.

남기춘, 임창국, 정재범, 김동휘, 편성범(1999). 브로카 실어증의 실문법증: 격조사산출과 이해의 해리. 심리학회지: 일반, 18, 49-64.

백경선(2004). 우뇌 손상자의 이야기 산출에서 의미내용과 담화 구조화의 분석. 언어청각장애연구, 9, 72-101.

변주영, 신지철, 김덕용, 김향희(2009). 유창성 실어증 환자의 자발화 이야기문법 특성. 언어청각장애연구, 14, 160-172.

손혜민(2004). 브로카 실어증 환자의 피동문 이해. 단국대학교대학원 석사학위논문.

양명진(2000). 브로카 실어증 환자의 담화 능력 분석: 일관성의 고찰. 연세대학교대학원 석사학위논문.

우인혜(1997). 우리말 피동 연구. 서울: 한국문화사.

윤정미, 김영태(2002). 브로카실어증 환자들의 동사이해결함의 범주특정적 특색. 언어청각장애연구, 7, 39-54. 
Hye Lim Kim, et al. • Syntactic Complexity in Discourse for Aphasia

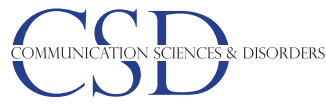

이동주, 연종흠, 황인범, 이상구(2010). 꼬꼬마: 관계형 데이터베이스를 활용한 세종 말뭉치 활용 도구. 정보과학회논문지: 컴퓨팅의 실제 및 레터, 16, 1046-1050.

이재성(2001). 한국어의 시제와상. 서울: 국학자료원.

최소영(2012). 한국 실어증 환자의 능·피동문 이해: 처리 손상 관점의 접근. 언어청각장애연구, 17,322-337.

황민아(2007). 한국 브로카 실어증 환자의 문장 이해. 언어청각장애연구, 7, 64-85.

황주희(2002). 브로카 실어증 환자들의 문장 이해에서 보조사 처리. 연세대학교대학원 석사학위논문. 